\title{
Foreign direct investment and economic growth in Zimbabwe: a dynamic causality test
}

\author{
Kunofiwa Tsaurai* \\ Department of Finance, \\ Risk Management and Banking, \\ University of South Africa, \\ P.O. Box 392, UNISA, \\ 0003, Pretoria, South Africa \\ E-mail: tsaurk@unisa.ac.za \\ E-mail: kunofiwa.tsaurai@gmail.com \\ *Corresponding author
}

\author{
Nicholas M. Odhiambo \\ Department of Economics, \\ University of South Africa, \\ P.O. Box 392, UNISA, \\ 0003, Pretoria, South Africa \\ E-mail: odhianm@unisa.ac.za \\ E-mail: nmbaya99@yahoo.com
}

\begin{abstract}
In this study we examine the dynamic causal relationship between foreign direct investment (FDI) and economic growth in Zimbabwe - using the modern time-series techniques. Specifically, we employ the ARDL-bounds testing approach to examine the FDI-growth linkage. We also employ the error-correction-based causality test, which captures both the short run and long run dynamics. Contrary to some of the previous studies, this study shows that there is a distinct causal flow from economic growth to FDI in Zimbabwe. The results apply irrespective of whether the causality test is conducted in the short run or in the long run. The study, therefore, recommends that Zimbabwe should pursue pro-growth strategies, in order to promote foreign direct investment.
\end{abstract}

Keywords: Zimbabwe; foreign direct investment; FDI; ARDL-bounds testing approach; economic growth.

Reference to this paper should be made as follows: Tsaurai, K. and Odhiambo, N.M. (2012) 'Foreign direct investment and economic growth in Zimbabwe: a dynamic causality test', Int. J. Economic Policy in Emerging Economies, Vol. 5, No. 2, pp.183-196.

Biographical notes: Kunofiwa Tsaurai is a Lecturer in Financial Management. His main areas of research interest include stock market development, foreign direct investment, monetary economics, international banking and finance, investments, credit management and risk management.

Nicholas M. Odhiambo is a Professor of Economics and the Chair of Growth, Poverty and Policy Modelling (GPPMR) Research. 


\section{Introduction}

The causal relationship between foreign direct investment (FDI) and economic growth has been a subject of extensive debate in finance and economics by various authors - with divergent and convergent views. According to Lean (2008), the relationship between FDI and economic growth in the Malaysian manufacturing sector is independent. In other words, no long-run relationship was found between FDI and GDP in the manufacturing sector during the study period of 1980 to 2005 . This finding is rather interesting because it contradicts most theoretical expectations of FDI-driven economic growth. According to Adams (2009b), although the flow of FDI increased for sub-Saharan African countries in the 1990s, the increase did not lead to a proportionate positive impact of FDI on economic growth. FDI crowds out domestic investment; hence, any positive effect of FDI on economic growth may be due to an increase in the total factor productivity rather than the augmentation of domestic capital (Adams, 2009b).

A study carried out by Won and Hsiao (2008) revealed strong bidirectional causality relations among FDI, exports and economic growth for the three first-generation Asian newly industrialised economies (ANIEs) ${ }^{1}$, but only statistically weak bidirectional causality between exports and GDP for the second-generation ANIEs ${ }^{2}$. Iqbal et al. (2010), in their study on Pakistan, concurred with Won and Hsiao (2008) on the bidirectional causality relationship among FDI, exports and economic growth.

Unfortunately, the relationship between FDI and economic growth in Zimbabwe, just as in other sub-Saharan African countries, has not received enough and satisfactory attention in the literature. There is, therefore, a need to shed more light on the relationship between FDI and economic growth in Zimbabwe. The results of this study will be valuable to economic policy makers, as it would enable them to understand the link between FDI and economic growth. This is particularly crucial for Zimbabwe, which is still in the process of recovering from a decade of economic challenges, and which needs the right policy mix, in order to adequately address its economic challenges.

It is against this background that this study attempts to investigate the causal linkage between FDI and economic growth in the Zimbabwean context - using the newly developed ARDL-bounds testing approach. The study uses real GDP per capita as a proxy for economic growth. The rest of the paper is structured as follows: Section 2 gives an overview of FDI and economic growth in Zimbabwe. Section 3 presents the theoretical and empirical literature review; while Section 4 deals with the empirical model specification, the estimation technique and the empirical analysis of the regression results. Section 5 concludes the study.

\section{FDI and economic growth in Zimbabwe}

Gwenhamo (2011) pointed out that the FDI net inflows in Zimbabwe were very low from 1980 to 1990 , as a result of the policy environment, which was unfavourable to foreign investors. These policies included the excessively long process required to approve foreign investors' proposals, ownership restrictions, which required at least $30 \%$ local participation in some sectors, and the restrictive repatriation of profits policy.

According to Gwenhamo (2011), the policies of the government of Zimbabwe towards foreign investors began to change in the late 1980s, as it came to grips with persistently low levels of FDI. The government adopted a new investment code in 1989. 
This was meant to increase the proportion of after-tax profits that multinational companies (MNCs) could repatriate: from $50 \%$ to $100 \%$. The IMF-funded economic structural adjustment programme (ESAP) was adopted by the government of Zimbabwe in 1990; and it encompassed measures that promoted FDI.

Figure 1 Net FDI inflows (US\$) in Zimbabwe 1990-2010 (see online version for colours)

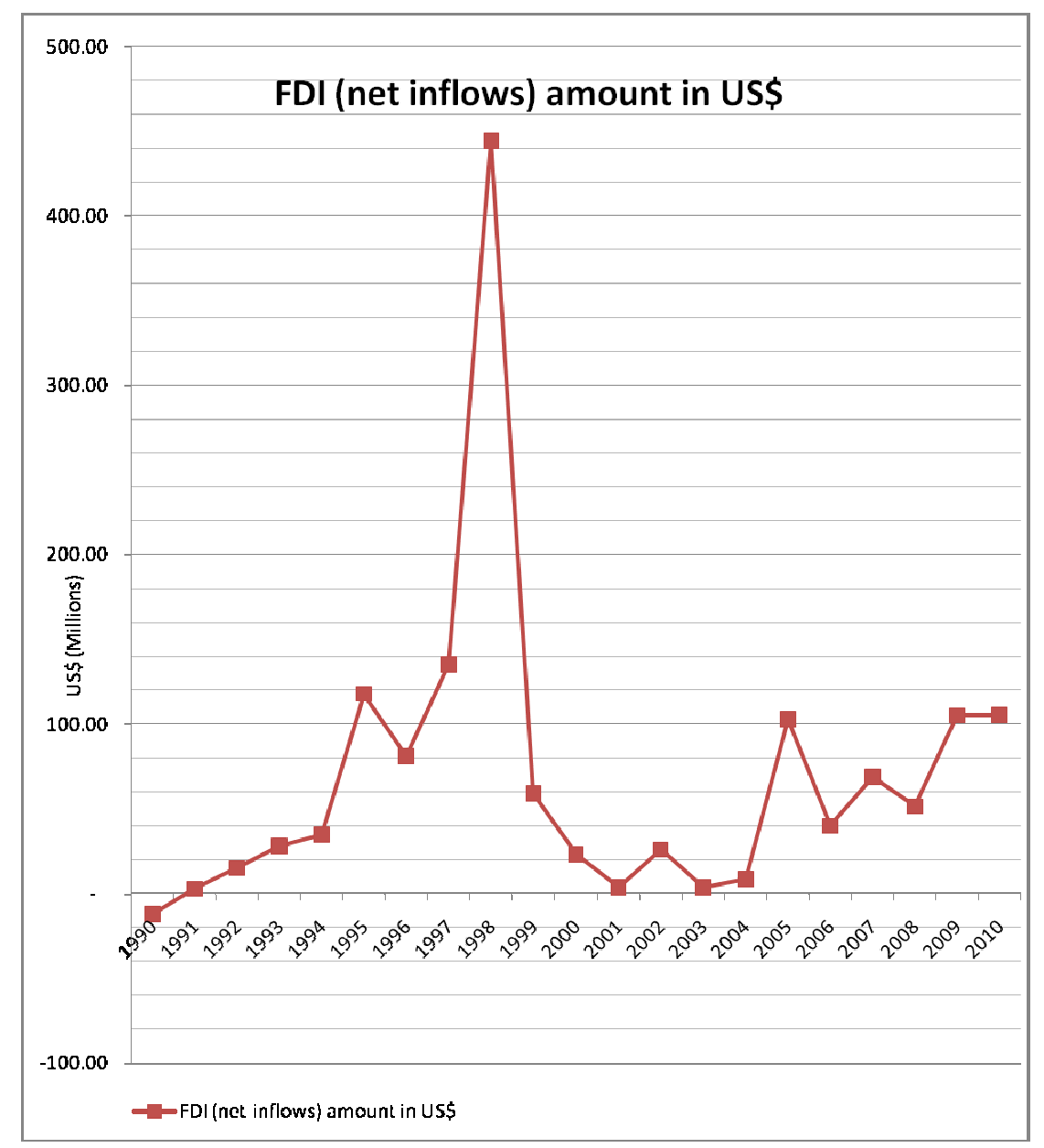

Source: Derived from world global statistical indicators (World Bank 2011).

In 1992, the Zimbabwe Investment Centre (ZIC) was established as a one-stop shop for the approval of FDI proposals. The enthusiastic promotion of FDI, coupled with a return to a liberal economy, resulted in the surge of FDI inflows averaging above US\$ 10 million per year between 1992 to 1997 - reaching a record high level of US\$ 444 million in 1998 (Gwenhamo, 2011). Figure 1 shows the net FDI inflows in Zimbabwe from 1990 to 2010 .

According to the World Bank (2011) ${ }^{3}$, FDI grew by $84 \%$ from 1980 to 1985 , whilst FDI as a percentage of GDP went up by $122 \%$ during the same period. The period from 1985 to 1990 saw FDI shrinking from a positive US\$ 2.85 million to a negative US\$ 
12.21 million, representing a 528\% downfall. The subsequent five-year period recorded a massive 1064\% surge in FDI net inflows, from a negative US\$12.21 million in 1990 to a positive US\$117.7 million in 1995.

According to the RBZ (1997) ${ }^{4}$, an analysis of the sectoral distribution of inward FDI from 1993 to 1997 shows that the mining sector has been the major beneficiary of FDI, followed by the manufacturing, and then the financial sector respectively (Reserve Bank, 1997). For example, in 1993, mining and the manufacturing sectors together received about $90 \%$ of the FDI inflows into Zimbabwe, whilst agriculture and commerce only received about $9.6 \%$ and $4.6 \%$, respectively. Other sectors started to benefit from FDI inflows by 1995, such as tourism, commerce, construction and agriculture. Although the manufacturing sector was the major beneficiary of FDI inflows in 1995 accounting for about $42 \%$, the year 1996 saw the mining sector receiving the highest FDI inflows of about $37 \%$. This was followed by tourism, which got about $25 \%$, and then construction and commercial sectors, which shared about 10\% each (RBZ, 1997). The year 1997 saw manufacturing, construction and commerce getting a significant portion of the FDI inflows, at the expense of the other economic sectors of Zimbabwe.

FDI went down by $80 \%$ from US\$ 117.7 million in 1995 to US\$ 23.2 million in 2000 , whilst FDI as a percentage of GDP also declined by $79 \%$ during the same period. According to Gwenhamo (2011), FDI net inflows in Zimbabwe totalled over US\$ 444 million in 1998; whilst by 2001, FDI net inflows had fallen to US\$ 3.8 million, reflected in the transformation of Zimbabwe's capital account balance from a surplus in 1995 equal to $7.1 \%$ of GDP, to a deficit in 2002 equal to $6.5 \%$ of GDP. Despite investor confidence being further rattled in 2000 when compulsory farm acquisitions enabled by an Act of parliament began, the net inflow of FDI in Zimbabwe went up by $343 \%$ from 2000 (US\$ 23.2 million) to 2005 (US\$ 102.8 million). Although FDI net inflows in Zimbabwe recorded a steady increase of 3\% during the period from 2005 to 2010, its contribution to the Zimbabwean economy declined by $23 \%$, as shown by the ratio of FDI as a percentage of GDP going down from 1.841 in 2005 to 1.410 in 2010.

There are three distinct phases from 1985 up to 2010 that describes the economic growth in Zimbabwe, with positive economic growth recorded from 1985 to 1990; negative economic growth from 1991 to 2008; whilst 2009 and 2010 comprised a recovery period, as shown in Figure 2.

According to the World Bank (2011) , GDP grew by 55.82\% from 1985 to 1990, whilst GDP per capita went up by $31.80 \%$ during the same period. The period from 1990 to 1995 saw the GDP shrinking from US\$ 8.7 billion to US\$ 7.1 billion, representing a $19.04 \%$ decline. The downfall in the economy of Zimbabwe persisted during the period 1995 to 2000, which saw GDP further dropping by 7.1\%, whilst GDP per capita went down by $13.22 \%$ during the same period. A negative growth in GDP, coupled with GDP per capita was further recorded during the period from 2000 to 2005. GDP went down from US\$ 6.6 billion in 2000 to US\$ 5.6 billion in 2005, whilst GDP per capita shrunk by $15.90 \%$, from US\$ 528 to US\$ 444 during the same period. On average, the economy of Zimbabwe shrunk by $36.44 \%$ from 1990 to 2005 in terms of GDP, whilst the GDP per capita also took a knock by $47.06 \%$ during the same period. Zimbabwe registered a positive GDP growth of $5.7 \%$ in 2009 , and $8.1 \%$ in 2010 . This positive growth was anchored by improved policies, a favourable external environment and off- budget donor support (Ministry of Finance) ${ }^{6}$. As a result, the economic recovery pushed up GDP by $33.86 \%$ and that of GDP per capita by $33.85 \%$ from 2005 to 2010 . 
Figure 2 Zimbabwe GDP per capita and GDP, growth rates (\%) from 1990 to 2010 on a five year interval (see online version for colours)

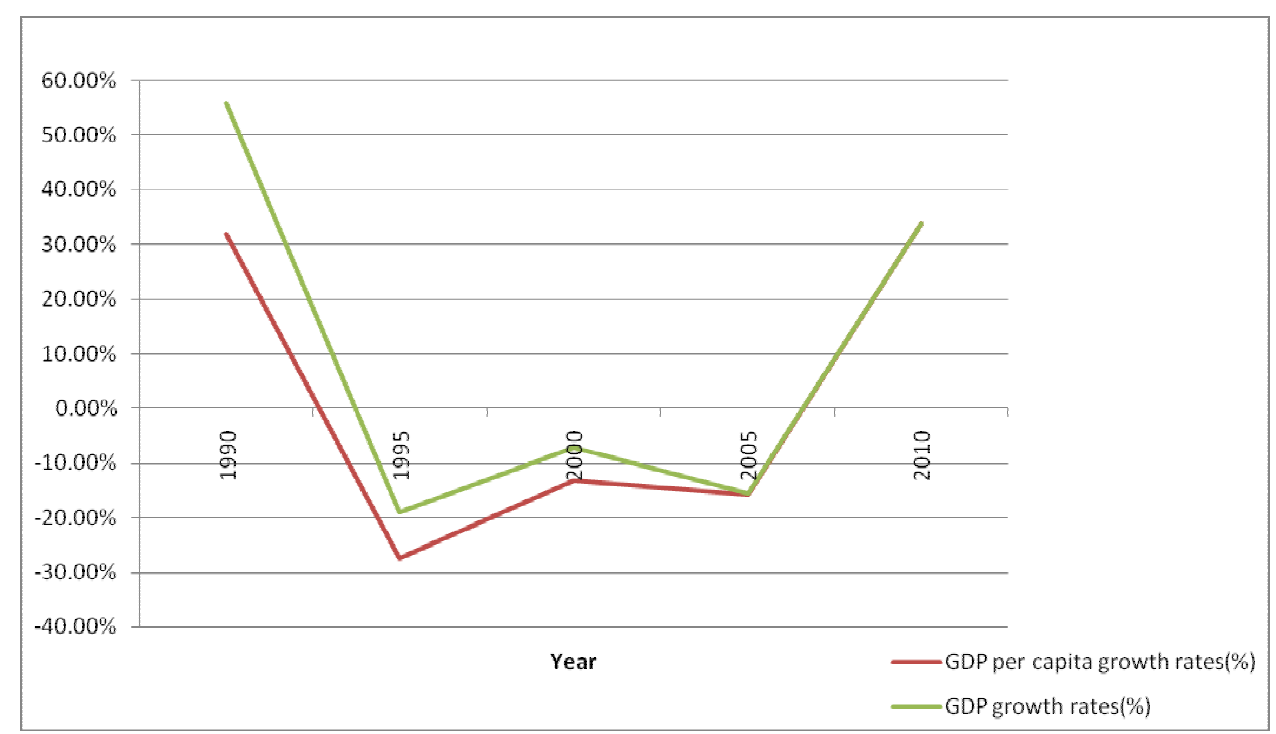

Source: Derived from World Bank Global Statistical Indicators (2011)

Impediments for further economic growth still persist in Zimbabwe, despite GDP for 2011 being expected to be one of the highest in Sub-Saharan countries at $9.3 \%{ }^{7}$. These impediments include a substantial fiscal financing gap, inefficient composition of public expenditure, financial sector vulnerabilities, weakness in the business climate worsened by the implementation of the indigenisation bill and the low savings rate, amongst others $(\mathrm{IMF}, 2011)^{8}$.

\section{FDI and economic growth: Theoretical and empirical overview}

There are many models and theories that have been used to explain the impact of FDI on economic growth. In this paper, however, we discuss four main theoretical perspectives, namely the modernisation theory, the dependency theory, the neoclassical growth theory and the endogenous growth theory. Studies consistent with the modernisation theory include those undertaken by Calvo and Sanchez-Robles (2002), Kumar and Pradhan (2002) and Nath (2005), among others. Calvo and Sanchez-Robles (2002) pointed out that the modernisation theory is based on a fundamental principle in economics that economic growth requires capital investment. They further highlighted the fact that the transfer of technology through FDI is important, because most developing countries lack the necessary infrastructure in terms of an educated population, liberalised markets, and social stability that are needed for innovation to promote economic growth. Kumar and Pradhan (2002) are two other proponents of the modernisation theory. They noted that, apart from technology and capital, FDI flows as a bundle of resources, including organisational and managerial skills, market know-how and market access - through the marketing networks of multinational enterprises. According to Nath (2005), FDI plays a 
twofold function in promoting economic growth - by contributing to capital accumulation and by increasing total factor productivity.

Studies consistent with the dependency theory include those undertaken by Bornschier and Chase-Dunn (1985), and Amin (1974), among others. Dependency theorists argued that reliance on FDI has a negative effect on economic growth and the distribution of income. According to Bornschier and Chase-Dunn (1985), FDI creates a predominantly monopolistic industrial structure - leading to the underutilisation of productive forces. Amin (1974) concurred; and further stated that the economy controlled by foreigners would not develop organically, but would rather grow in a disarticulated manner.

Solow (1956) and Swan (1956), the proponents of the neoclassical growth theory, stipulated that changes in capital stock affect short-run economic growth. FDI is an addition to the physical capital stock in the economy; and hence it affects economic growth in the short run only, according to Solow (1956). Swan (1956) likened the effect of an increase in FDI to the effect of an increase in savings, as FDI simply comprises foreign savings transferred to the host economy. On the other hand, the endogenous growth theory, according to Romer (1986) and Lucas (1988), stipulates that FDI is accompanied by the transfer of technology, know-how and the training of labour, all of which contribute to the accumulation of human capital and induce technological progress that helps the host country to achieve sustained and long-run economic growth.

Against the background of the conflicting theoretical views, many empirical studies have examined the relationship between FDI and economic growth in developing countries. These include those undertaken by Bogahawatte and Balamurali (2004), Vita and Kyaw (2009), Baharumshah and Almasaied (2009), Tanggapantnam et al. (2011), Adams (2009a, 2009b) and Ang (2008), amongst others.

Studies that explain the relationship between FDI and economic growth are grouped into four views. The first view maintains that FDI spurs economic growth. Studies consistent with this view include those undertaken by Bogahawatte and Balamurali (2004), Wang and Xie (2004), Eller et al.(2006), Vita and Kyaw (2009), Baharumshah and Almasaied (2009), Vu and Noy (2009), Adams (2009a, 2009b), Ekanayake and Ledgerwood (2010), Hoang et al. (2010), Tanggapantnam et al. (2011), and Ang (2009), amongst others.

Bogahawatte and Balamurali (2004), in their study, discovered that FDI exerted a strong positive influence on economic growth in Sri Lanka. Whilst Wang and Xie (2004) concurred with Bogahawatte and Balamurali (2004); their research revealed a weak influence of FDI on economic growth. In order to benefit from the technological spillovers of FDI, so as to persistently promote economic growth, host countries should design good institutes and infrastructure (Wang and Xie, 2004). Moreover, Eller et al. (2006) revealed that the impact of financial sector foreign direct investment (FSFDI) on economic growth depends on the stage of economic development of the host country. Their study found out that later-stage FSFDI was more beneficial to economic growth and development in Central and Eastern Europe when compared with the earlier stages of FSFDI.

Eller et al. (2006) found that beyond a certain threshold of economic development, the crowding out, of local physical capital caused by the entry of foreign banks seemed to have hampered economic growth in Central and Eastern Europe. Vita and Kyaw (2009), in their study, found results that were similar to those of Eller et al. (2006). Their research revealed that only countries whose economies have reached a minimum 
level of economic development and absorptive capacity can capture the economic growth-enhancing effects of FDI investment inflows.

Baharumshah and Almasaied (2009) discovered a significant and positive relationship between FDI, human capital and financial deepening on economic growth in their study of Malaysia. They also found that the effect of FDI on economic growth was one of lesser magnitude than that of domestic investment. By virtue of their interaction with FDI, human capital and financial markets were found to have both short and long-term impacts on economic growth. $\mathrm{Vu}$ and Noy (2009) revealed, in their study, that the significant positive relationship between FDI and economic growth was not equally distributed across all the economic sectors.

A study by Adams (2009a) revealed that FDI contributes to economic growth in a host country by augmenting domestic capital and enhancing efficiency through the transfer of new technology, marketing and managerial skills. His research discovered that FDI is necessary, but not a sufficient condition for economic growth. The extent to which the economy can benefit from FDI inflows depends on the host country's specific conditions, and the policy environment in particular, and the opportunities for linkages between FDI and domestic investment (Adams, 2009a).

Ekanayake and Ledgerwood (2010) concurred with Adams (2009a) in their study on the issue of the positive and significant impact of FDI on economic growth in developing countries. Furthermore, FDI was found to have a strong impact on economic growth in Vietnam, by a study carried out by Hoang et al. (2010). Their study further revealed that the additional capital from FDI inflow is the only channel that helps to increase the economic growth, whilst advanced technology and knowledge transfer from the FDI inflows were found to have no significant effect on economic growth in Vietnam. The findings by Feridun (2004) supported the FDI-led growth hypothesis, since the study revealed a unidirectional Granger causality running from FDI to economic growth in Cyprus. In addition, the study also discovered that economic growth and development would rely heavily on the quantity of FDI inflows into Cyprus (Feridun, 2004). In contrast, Wang (2009) discovered that only the manufacturing sector FDI inflows had a positive and significant impact on economic growth, whilst the non-manufacturing sector FDI inflows had a positive but very insignificant influence on the economy.

According to Tanggapantnam et al. (2011), there is an indirect relationship between FDI and economic growth. Their study discovered that human capital development, financial development and environmental conditions are all important preconditions for FDI to have a positive effect on economic growth. Ang (2009) concurred with the findings of Tanggapantnam et al. (2011) and emphasised that FDI can have a negative impact on output expansion in the long run if the level of financial development is quite low. According to Ang (2009), the efficiency of the financial system of the host country is a prerequisite to realising the economic benefits from FDI.

The second view states that economic growth promotes FDI. Studies consistent with this view include those undertaken by Ang (2008) and Sun (2011), amongst others. Ang (2008) found that real GDP had a significant positive impact on FDI inflows in Malaysia. In other words, the research discovered evidence that the growth rates of GDP exerted a positive impact on inward FDI in Malaysia. A $1 \%$ rise in real GDP resulted in a $0.95 \%$ increase in the FDI inflows in Malaysia (Ang, 2008). The study by Sun (2011) also showed one-way causality from economic growth to FDI inflows in China. This view 
was supported by Chowdhury and Mavrotas (2005), whose findings revealed a unidirectional causality running from GDP to FDI inflows in Chile.

The third view maintains that both FDI and economic growth promote each other. Studies consistent with this view include those undertaken by $\mathrm{Li}$ and Liu (2005), Gao (2005), Chakraborty and Nunnenkamp (2008), amongst others. According to Li and Liu (2005), there is a strong complementary connection between FDI and economic growth in both developed and developing countries. Their study found that the promotion of human capital, technological capabilities and economic growth would lead to more FDI inflows; and this would, in turn, promote further economic growth and competitiveness.

Gao (2005) revealed that the positive correlation between FDI and economic growth was a result of both of them responding endogenously to economic integration - without necessarily implying any causal relationship. Economic integration gives rise to FDI; and this leads to an expansion of research and development activity; and it increases the world economic growth rate (Gao, 2005).

Chakraborty and Nunnenkamp (2008) discovered that at the aggregate level, Granger causality tests showed feedback effects between FDI and output, both in the short and long run in India. They also found that the impact of output growth in attracting FDI was found to be relatively stronger than that of FDI in inducing economic growth. In addition, the positive impact of FDI on economic growth in India was discovered by Chakraborty and Nunnenkamp (2008) to be largely restricted to the manufacturing sector; whilst no evidence of any causal relationship in the primary sector between FDI and economic growth in India was found. Dash and Sharma (2011) concurred in their findings that the causal relationship between FDI and economic growth is bidirectional. This view was supported by Chowdhury and Mavrotas (2005), whose study showed a strong bidirectional causal relationship between FDI and economic growth in both Malaysia and Thailand.

The fourth view states that there is no relationship at all between FDI and economic growth. Studies consistent with this view include those undertaken by Yan and Pokhrel (2011), Lean (2008) and Naguib (2012), Lyroudi and Apergis (2008), amongst others. The study by Yan and Pokhrel (2010) could not find a direct way of identifying the linkage between FDI and GDP in Nepal. Lean (2008) also found that FDI in the manufacturing sector of Malaysia and economic growth were independent of each other. His study specifically discovered that there is no short and long-run relationship running from FDI to GDP, or vice-versa, in the manufacturing sector of Malaysia from 1980 to 2005. According to Lean (2008), challenges, such as corruption, ethnicity-based ownership restrictions, regulatory barriers to business operations and restrictions on capital flows need to be addressed, in order to enhance the impact of FDI on economic growth.

Naguib (2012) came up with a similar finding in a research on the impact of FDI and privatisation on economic growth in Argentina. Even the Wald test failed to reject the hypothesis that the overall effect of FDI on economic growth in the short run is zero; whilst the results of the co-integration vector also indicated that FDI has insignificant effects on economic growth in the long run (Naguib, 2012). Lyroudi and Apergis (2008) also discovered a very low and insignificant relationship between FDI and economic growth in low-income economies, which experienced failed privatisation programmes. Bilgic (2007) in a study on Turkey found no causality relationship, either from economic growth to FDI, or from FDI to economic growth, both in the short and long run. 


\section{Empirical model specification and estimation techniques}

\subsection{Data sources and definition of variables}

This study uses annual time series data for the period between 1980 and 2010. All the data used in this study were obtained from the various issues of the International Financial Statistics (IFS) yearbook and world development indicators. The FDI variable was computed as total FDI as a ratio of GDP. The economic growth, on the other hand, was measured by real GDP per capita.

\subsection{Unit root tests}

Before the variables FDI and real GDP per capita were tested for co-integration - using the ARDL-bounds testing approach, the data sets of two variables were tested for unit root - using the Philips-Peron and ADF-GLS tests. The results of the stationarity tests on differenced variables are presented in Table 1.

Table 1 Stationarity tests of variables on first difference - Phillips-Perron (PP) and GF-GLS tests

\begin{tabular}{lcc}
\hline Variable & No trend & \multicolumn{1}{c}{ Trend } \\
\hline Stationarity Tests of Variables on first Difference - Phillips-Perron (PP) Test \\
DFDI & $-11.8308^{* * *}$ & $-11.53726^{* * *}$ \\
DLy/N & $-3.851283^{* * *}$ & $-3.963407 * * *$ \\
Stationarity Tests of Variables on first Difference - Dickey-Fuller - GLS Test \\
DFDI & $-8.157209^{* * *}$ & $-8.159463 * * *$ \\
DLy/N & $-3.198414 * * *$ & $-3.865870^{* * *}$ \\
\hline
\end{tabular}

Notes: (1) The truncation lag for the PP tests is based on Newey and West (1987) bandwidth. (2)*** denotes $1 \%$ level of significance. (3) Critical values for Dickey-Fuller GLS test are based on Elliot et al. (1996, Table 1).

The results of the unit root tests reported in Table 1 show that both variables are integrated of order 1 .

\subsection{Cointegration test-ARDL-bounds testing procedure}

In order to test for the existence of co-integration between FDI and real GDP per capita, we use the recently developed ARDL-bounds testing approach. The ARDL model used in this study can be expressed as follows:

$$
\begin{aligned}
& \Delta I n y / N_{t}=a_{0}+\sum_{i=1}^{n} a_{1 i} \Delta I n y / N_{t-i}+\sum_{i=0}^{n} a_{2 i} \Delta I n F D I_{t-i} \\
& +a_{3} \operatorname{Iny} / N_{t-1}+a_{4} \operatorname{InFDI}_{t-1}+\mu_{t} \\
& \Delta I n F D I_{t}=\beta_{0}+\sum_{i=1}^{n} \beta_{1 i} \Delta I n F D I_{t-i}+\sum_{i=0}^{n} \beta_{2 i} I n y / N_{t-i} \\
& +\beta_{3} \operatorname{Iny} / N_{t-1}+\beta_{4 I I n F D I} I_{t-1}+\mu_{t}
\end{aligned}
$$

where: In $F D I=$ FDI; y $/ \mathrm{N}=$ Real GDP per capita; $\Delta=$ first difference operator. 
The first step of the ARDL-bounds test involves examining the order of lags on the first differenced variables in equations (1) and (2) - using the Akaike Information Criterion (AIC) and the Schwartz-Bayesian Criterion (SBC). The results of the AIC and SBC tests (not reported here) show that the optimal lag of FDI is three; while that of real GDP per capita is lag 1. In the second step, we apply the bounds F-test to equations (1) and (2), in order to establish whether there exists any long-run relationship between the variables under study. The results of the bounds test are reported in Table 2.

Table 2 Bounds F-test for cointegration

\begin{tabular}{|c|c|c|c|c|c|c|}
\hline Dependent variable & \multicolumn{2}{|c|}{ Function } & \multicolumn{4}{|c|}{ F-test statistic } \\
\hline FDI & \multicolumn{2}{|c|}{$\mathrm{FDI}(\mathrm{y} / \mathrm{N})$} & \multicolumn{4}{|c|}{$4.440 * *$} \\
\hline$y / N$ & \multicolumn{2}{|c|}{$\mathrm{y} / \mathrm{N}(\mathrm{FDI})$} & \multicolumn{4}{|c|}{1.040} \\
\hline \multicolumn{7}{|l|}{ Asymptotic critical values } \\
\hline & \multicolumn{2}{|c|}{$1 \%$} & \multicolumn{2}{|c|}{$5 \%$} & \multicolumn{2}{|c|}{$10 \%$} \\
\hline & $\mathrm{I}(0)$ & $\mathrm{I}(1)$ & $\mathrm{I}(0)$ & $\mathrm{I}(1)$ & $\mathrm{I}(0)$ & $\mathrm{I}(1)$ \\
\hline $\begin{array}{l}\text { Pesaran et al. (2001), p.300, } \\
\text { Table CI(ii) Case II }\end{array}$ & 4.94 & 5.58 & 3.62 & 4.16 & 3.02 & 3.51 \\
\hline
\end{tabular}

Note: $* *$ denotes statistical significance at the $5 \%$ level

The results reported in Table 2 show that there exists a unique co-integrating vector between FDI and real GDP per capita, when FDI is used as the endogenous variable. This is confirmed by the F-statistic in the FDI equation, which is statistically significant.

\subsection{Granger non-causality test}

Having confirmed the existence of the long-run relationships been FDI and real GDP per capita, the next step is to examine the Granger-causality between the two variables. The direction of the Granger-causality in this case can be tested by using the following model (see Odhiambo, 2010; Narayan and Smyth, 2008).

$$
\begin{aligned}
& \Delta I n y / N_{t}=\varphi_{0}+\sum_{i=1}^{n} \varphi_{1 i} \Delta I n y / N_{t-i}+\sum_{i=0}^{n} \varphi_{2 i} \Delta I n F D I_{t-i}+E C M_{t-1}+\mu_{t} \\
& \Delta I n F D I_{t}=\delta_{0}+\sum_{i=1}^{n} \delta_{1 i} \Delta I n F D I_{t-i}+\sum_{i=0}^{n} \delta_{2 i} \Delta I n y / N_{t-i}+E C M_{t-1}+\mu_{t}
\end{aligned}
$$

where $E C M_{t-1}=$ the lagged error-correction term obtained from the long-run equilibrium relationship.

The direction of the causality between FDI and economic growth in this case is determined by the F-statistic and the lagged error-correction term. The F-statistic on the explanatory variables represents the short-run causal effect; while the t statistic on the coefficient of the lagged error-correction term represents the long-run causal relationship (see Odhiambo, 2010; Narayan and Smyth, 2006). The results of these causality tests are reported in Table 3. 
Table 3 Granger non-causality tests

\begin{tabular}{lcccc}
\hline Dependent variable & Causal flow & F-Statistic & t-Test on ECM & $R^{2}$ \\
\hline $\begin{array}{l}\text { Foreign direct } \\
\text { investment (FDI) }\end{array}$ & Economic growth $(\mathrm{y} / \mathrm{N}) \rightarrow$ FDI & $8.6369^{* * *}$ & $-5.229^{* * *}$ & 0.95 \\
Economic growth $(\mathrm{y} / \mathrm{N})$ & FDI $\rightarrow$ economic growth $(\mathrm{y} / \mathrm{N})$ & 0.6249 & - & 0.50 \\
\hline
\end{tabular}

Note: $* * *$ denotes statistical significance at the $1 \%$ level

The empirical results reported in Table 3 show that there is a unidirectional causal flow from economic growth $(\mathrm{y} / \mathrm{N})$ to FDI - both in the short run and in the long run. Both the F-statistics and the coefficient of the error-correction term in the FDI function are statistically significant - as was expected. The causal flow from FDI to economic growth is, however, rejected by the F-statistic and the coefficient of the error-correction term, which are statistically insignificant.

\section{Conclusions}

This study has examined the dynamic relationship between FDI and economic growth in Zimbabwe - using time-series data. The causal relationship between FDI and economic growth has been a subject of extensive debate in recent years. Currently, there exist three views regarding the relationship between FDI and economic growth. The first view maintains that it is FDI that drives the real sector development. The second view argues that it is the real sector development (economic growth) that spurs FDI. The third view maintains that both FDI and economic growth promote each other. Finally, the fourth view is that there is no relationship at all between FDI and economic growth. Unlike the previous studies, the current study uses the ARDL-bounds testing approach to examine this linkage. In order to examine the order of integration, the study uses the PhillipsPerron and the ADF-GLS unit root tests - both with trend and without trend. The study has also employed the error-correction-based causality test, which captures both the short run and long-run dynamics. Contrary to some of the previous studies, the current study shows that there is a distinct unidirectional causal flow from economic growth to FDI, but not vice versa. The results apply, irrespective of whether the causality test is conducted in the short run or in the long run. The study, therefore, recommends that Zimbabwe should pursue pro-growth policies and strategies, in order to promote FDI.

\section{References}

Adams, S. (2009a) 'Can foreign direct investment help to promote growth in Africa?', African Journal of Business Management, Vol. 3, No. 5, pp.178-183.

Adams, S. (2009b) 'Foreign direct investment, domestic investment and economic growth in sub-Saharan Africa', Journal of Policy Modeling, Vol. 31, No. 6, pp.939-949.

Amin, S. (1974) Accumulation on a World Scale: a Critique of the Theory of Underdevelopment, Monthly Review Press, New York.

Ang, J.B. (2008) 'Determinants of foreign direct investment in Malaysia', Journal of Policy Modeling, Vol. 30, No. 1, pp.185-189.

Ang, J.B. (2009) 'Foreign direct investment and its impact on the Thai economy: the role of financial development', Journal of Economics and Finance, Vol. 33, No. 3, pp.316-323. 
Baharumshah, A.Z. and Almasaied, S.W. (2009) 'Foreign direct investment and economic growth in Malaysia: interactions with human capital and financial deepening', Emerging Markets Finance and Trade Journal, Vol. 45, No. 1, pp.90-102.

Bilgic, E. (2007) 'Causal relationship between foreign direct investment and economic growth in Turkey', Masters degree project in Economics and Finance, School of Technology and Society.

Bogahawatte, C. and Balamurali, N. (2004) 'Foreign direct investment and economic growth in Sri Lanka', Sri Lanka Journal of Agricultural Economics, Vol. 6, No. 1, pp.37-50.

Bornschier, V. and Chase-Dunn, C. (1985) Transnational Corporations and Underdevelopment, Praeger, New York.

Calvo, M.B. and Sanchez-Robles, B. (2002) 'Foreign direct investment, economic freedom and economic growth: new evidence from Latin America', Universidad de Cartabria, Economics Working Paper No. 4/03.

Chakraborty, C. and Nunnenkamp, P. (2008) 'Economic reforms, FDI and Economic growth in India: a sector level analysis', World Development, Vol. 36, No. 7, pp.1192-1212.

Chowdhury, A. and Mavrotas, G. (2005) 'FDI and growth: a causal relationship', World Institute for Development Economics Research, Research Paper No. 2005/25.

Dash, R.K. and Sharma, C. (2011) 'FDI, trade and growth dynamics: new evidence from the postreform India', The International Trade Journal, Vol. 25, No. 2, pp.233-266.

Ekanayake, E.M. and Ledgerwood, J.R. (2010) 'How does foreign direct investment affect growth in developing countries? An empirical investigation', The International Journal of Business and Finance Research, Vol. 4, No. 3, pp.43-53.

Eller, M., Haiss, P. and Steiner, K. (2006) 'Foreign direct investment in the financial sector and economic growth in Central and Eastern Europe: the crucial role of the efficiency channel', Emerging Markets Review, Vol. 7, No. 4, pp.300-319.

Elliot, G., Rothenberg, T. and Stock, J. (1996) 'Efficient tests for an autoregressive unit root', Econometrica, Vol. 64, No. 4, pp.813-836.

Feridun, M. (2004) 'Foreign direct investment and economic growth: a causality analysis for Cyprus', Journal of Applied Sciences, Vol. 4, No. 4, pp.654-657.

Gao, T. (2005) 'Foreign direct investment and growth under economic integration', Journal of International Economics, Vol. 67, No. 1, pp.157-174.

Gwenhamo, F. (2011) 'Foreign direct investment in Zimbabwe: the role of institutional and macroeconomic factors', South African Journal of Economics, Vol. 79, No. 3, pp.211-223.

Hoang, T.T., Wiboonchutikula, P. and Tubtimtong, B. (2010) 'Does foreign direct investment promote economic growth in Vietnam?', ASEAN Economic Bulletin, Vol. 27, No. 3, pp.295-311.

Iqbal, M.S., Shaikh, F.M. and Shar, A.H. (2010) 'Causality relationship between foreign direct investment, trade and economic growth in Pakistan', Asian Social Science, Vol. 6, No. 9, pp.82-89.

Kumar, N. and Pradhan, J.P. (2002) 'FDI, externalities and economic growth in developing countries: some empirical explorations and implications for WTO negotiations on investment', RIS Discussion Paper No. 27/2002. New Delhi, India.

Lean (2008) 'The impact of foreign direct investment on the growth of the manufacturing sector in Malaysia', International Applied Economics and Management Letters, Vol. 1, No. 1, pp.41-45.

Li, X. and Liu, X. (2005) 'Foreign direct investment and economic growth: an increasingly endogenous relationship', World Development, Vol. 33, No. 3, pp.393-407.

Lucas, R. (1988) 'On the mechanics of economic development', Journal of Monetary Economics, Vol. 22, No. 1, pp.3-42. 
Lyroudi, K. and Apergis, N. (2008) 'The relationship between foreign direct investment and economic growth: evidence from transition countries', Transition Studies Review, Vol. 15, No. 1, pp.37-51.

Naguib, R.I. (2012) 'The effects of privatization and foreign direct investment on economic growth in Argentina: an international and comparative review', The Journal of International Trade and Economic Development, Vol. 21, No. 1, pp.51-82.

Narayan, P.K. and Smyth, R. (2006) 'Higher education, real income and real investment in China: evidence from Granger causality tests', Education Economics, Vol. 14, No. 1, pp.107-125.

Narayan, P.K. and Smyth, R. (2008) 'Energy consumption and real GDP in G7 countries: new evidence from panel cointegration with structural breaks', Energy Economics, Vol. 30, No. 5, pp.2331-2341.

Nath, H. (2005) 'Trade, foreign direct investment and growth: evidence from transition economies', SHSU Economics and International Business Working Paper No. SHSU-Eco-WP05-04, Sam Houston State University, Huntsville, TX.

Newey, W.K. and West, K.D. (1987) 'A simple, positive semi-definite, heteroskedasticity and auto-correlation consistent covariance matrix', Econometrica, Vol. 55, No. 3, pp.703-708.

Odhiambo, N.M. (2010) 'Finance-investment-growth nexus in South Africa: an ARDL-bounds testing approach', Economic Change and Restructuring, Vol. 43, No. 3, pp.205-219.

Pesaran, M., Shin, Y. and Smith, R. (2001) 'Bounds testing approaches to the analysis of level relationships', Journal of Applied Econometrics, Vol. 16, No. 3, pp.289-326.

RBZ (1997) 'Reserve Bank of Zimbabwe', Monthly Economic Bulletin, May, pp.5-7.

Romer, P. (1986) 'Increasing returns and long run economic growth', Journal of Political Economy, Vol. 94, No. 5, pp.1002-1037.

Solow, R. (1956) 'A contribution to the theory of economic growth', Quarterly Journal of Economics, Vol. 70, No. 1, pp.65-94.

Sun, H. (2011) 'Co-integration study of relationship between foreign direct investment and economic growth', International Business Research, Vol. 4, No. 4, pp.226-230.

Swan, T. (1956) 'Economic growth and capital accumulation', The Economic Record, Vol. 32, No. 2, pp.334-361.

Tanggapantnam, D., Geetha, C., Mohidin, R. and Vincent, V. (2011) 'The relationship between economic growth and foreign direct investment in Malaysia: analysis based on location advantage theory', International Journal of Economics and Management Science, Vol. 1, No. 2, pp.24-31.

Vita., G. and Kyaw, K. (2009) 'Growth effects of FDI and portfolio investment flows to developing countries: a disaggregated analysis by income levels', Applied Economics Letters, Vol. 16, No. 3, pp.277-283.

Vu, T.B. and Noy, I. (2009) 'Sectoral analysis of foreign direct investment and growth in the developed countries', Journal of International Financial Markets, Institutions \& Money, Vol. 19, No. 2, pp.402-413.

Wang, H. and Xie, X. (2004) 'On effects of foreign direct investment on economic growth', International Business Research Journal, Vol. 2, No. 4, pp.100-108.

Wang, M. (2009) 'Manufacturing FDI and economic growth: evidence from Asian economies', Applied Economics, Vol. 41, No. 8, pp.991-1002.

Won, Y. and Hsiao, F.S.T. (2008) 'Panel causality analysis on FDI: exports-economic growth nexus in first and second generation ANIEs', The Journal of the Korean Economy, Vol. 9, No. 2, pp.237-267.

Yan, X. and Pokhrel, M.K. (2011) 'Relationship between foreign direct investment and economic growth in Nepal', International Journal of Business and Management, Vol. 6, No. 6, pp.242-246. 


\section{Notes}

1 The economies of Korea, Taiwan and Singapore.

2 The economies of Malaysia, Philippines, Thailand and China.

3 Derived from World Global Statistical Indicators (World Bank 2011).

4 Reserve Bank of Zimbabwe, Monthly Economic Bulletin, May 1997.

5 Derived from World Global Statistical Indicators (World Bank 2011).

6 Minister of Finance of Zimbabwe 2012 budget statement, (November 2011).

7 Minister of Finance of Zimbabwe 2012 budget statement, (November 2011).

8 IMF report on Zimbabwe (2011). 